\title{
Freight Logistics: A New Area for Cooperation Between Korea and Australia?
}

\begin{abstract}
Peter J. Rimmer*
The governments of Australia and the Republic of Korea recognize the importance of freight logistics in improving national competitive advantage. As they are seeking to capitalize on the economy-wide benefits to be derived from a world-class freight logistics industry, there is a need to keep abreast of their respective freight logistics policy initiatives as the basis for exploring prospects for mutual cooperation within the broader Asian-Pacific context. Attention here is focused on evaluating the Australian Government's Freight Transport Logistics Industry Action Agenda to reflect on its relevance to the Korean Government's aspirations to become the Business Hub of Northeast Asia as envisioned in the Presidential Committee's Road Map for Promoting Northeast Asian Logistics Hub.
\end{abstract}

\section{INTRODUCTION}

Since the 1960s Australia's trading relationship with the Republic of Korea (ROK) has been commodity-based. Traditionally, Australia has been a supplier of crude petroleum, coal, non-monetary gold, iron ore, aluminium, auto components, beef and wool. In return Korea has exported telecommunications equipment, nonmonetary gold, passenger motor vehicles, televisions, computers, heating and cooling equipment, household appliances and rubber tyres (Masamune, 2003). By 2002 Korea was Australia's third largest export destination (8.3 per cent of Australia's exports) and Korea' s fifth largest import source (3.7 per cent of Korea's imports). In the same year Australia was Korea's fifth largest study abroad market with 12,563 students and 189,000 Koreans visited Australia. There were 229 cases of Korean investment in Australia worth a total of US\$894 million and 143 cases of Australian investment in Korea worth a total of US\$416 million. In response to global and technological changes the Governments of both countries are ready to build on these investments and enter into a deeper economic and cultural partnership. Already the strength of the respective economies offers good prospects for the further trade expansion into telecommunications, technology and education.

Newer areas of cooperation between Australia and Korea need to be explored, such as freight logistics, which, according to the Commonwealth of Australia (COA, 2002a; 5), covers 'everything to do with freight' .

* Emeritus Professor and Visiting Fellow, Division of Pacific and Asian History, Research School of Pacific and Asian Studies, The Australian National University, and Adjunct Professor of Urban Development and Housing, The University of Canberra, Australia. E-mail: pjrimmer @coombs.anu.edu.au. Ian Heyward drew the accompanying figures and Dr. Sue Rimmer provided editorial comments and made important suggestions on structuring the paper. 
In other words, freight logistics 'involves the movement, storage and handling of goods and materials across the entire logistics chain from producer to consumer, from point of origin to point of demand' (COA, 2002a: ix). As such, the freight logistics industry facilitates both domestic and international trade and is a key factor in maintaining a country's standard of living (Figure 1). Logistics chain management produces maximum profits from 'applying logistics management - minimising costs and supply chain management - maximising returns' (COA, 2002a: 6). A common plaint from logistics chain managers in both Australia and Korea is that few people appreciate either the complexity involved in coordinating the apparently simple tasks of sourcing, purchasing, packaging, warehousing and transporting, storing and delivering freight and disposing of waste, or the logistic industry's economic importance and significance in everyday life. Efficient and effective logistics are regarded as being critical to a firm's competitive position. Driven by globalization, national governments are recognizing the importance of logistics policy in improving their national competitive advantage and seeking to capitalize on the economy-wide benefits to be derived from a world-class freight logistics industry: a greater market reach, a wider choice of inputs and products, and less waste within the economy (COA, 2002a: 14, 26).

Figure 1. The global hub-and-spoke system

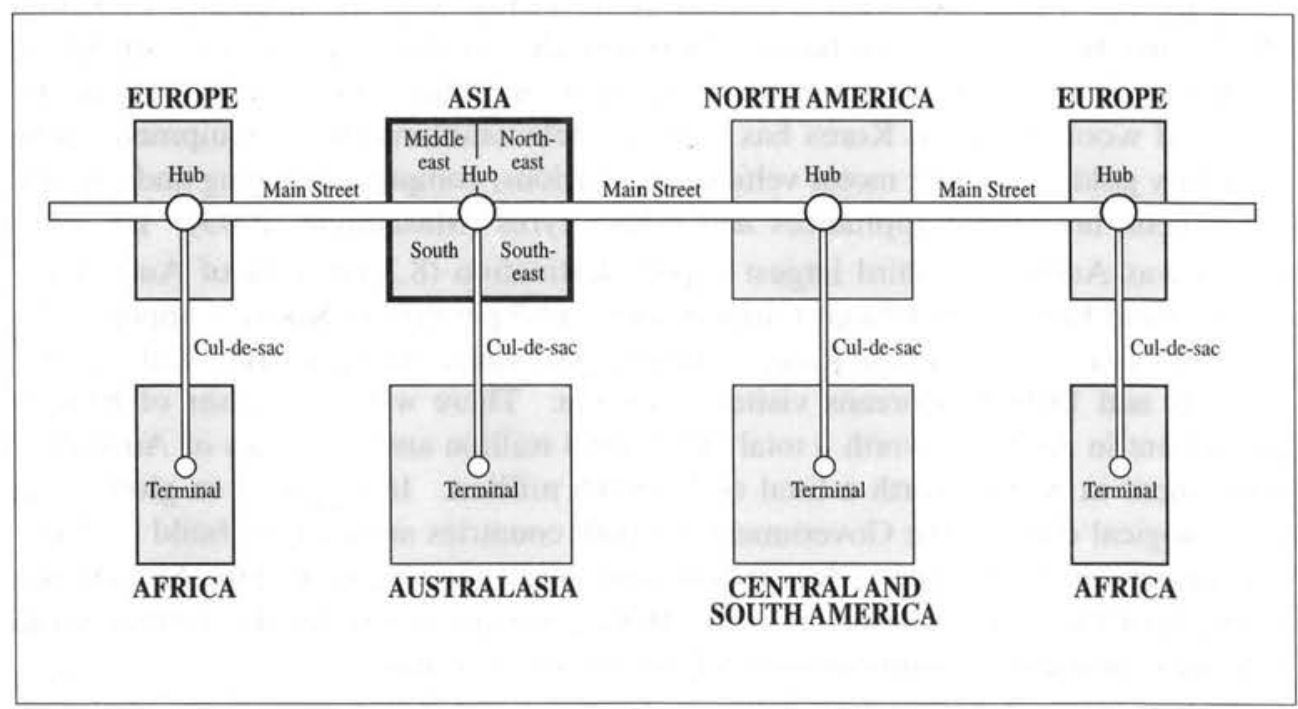

Source: based on Rimmer (2001:37)

Since 2000 the Australian Government, as outlined by its Department of Industry, Science and Technology (DIST, n.d.), has adopted Action Agendas as a means of implementing its industry policy Investing for Growth. Action Agendas are a key element of the Government's policy of building 'a dynamic partnership between industry and government in order to achieve the common goal of sustainable economic growth in a global environment' (COA, 2002a: xi). 
In May 2000 the Government instituted the Freight Transport Logistics Industry Action Agenda, which 'aims to identify and address impediments to growth and the opportunity to create a sustainable, internationally competitive freight transport logistics industry' (DOTARS, 2001: 1).

The Action Agenda explored the likely future of freight logistics and its potential influence on the Australian economy. In focusing on the national freight logistics industry the Action Agenda addressed the role of in-house logistics professionals because they will also affect the industry's future directions of logistics services. Besides improving the relationship between industry and government the Action Agenda aims to examine and capitalize on opportunities for growth and generate 'the momentum for freight logistics firms, and their customers, to use their initiative to create a dynamic and internationally competitive freight logistics industry' (COA, 2002a: xi). A major outcome of the Australian Government's initiative has been a comprehensive report entitled Freight Logistics in Australia: An Agenda for Action, which was produced by an Industry Steering Committee comprising a core group of participants from the freight logistics industry and its stakeholders (COA, 2002a).

Meanwhile the Korean Government has been seeking to establish the country as a Business Hub for Northeast Asia to take advantage of its pivotal geo-economic position sandwiched between China and Japan by developing logistics, industrial innovation clusters and a financial center in a bid to stay ahead of China. Subsequently, the Presidential Committee on Northeast Asian Business Hub (PCNABH, 2003), has developed A Road Map for Promoting Northeast Asian Logistics $H u b$, which offers a vision, considers strategies and outlines future prospects. Initially, the Committee laments missed opportunities for timely investment in airports and seaports, the lack of logistics professionals and third party logistics (3PL) providers, the shortcomings of railroads and ports stemming from the preoccupation with road investment, the small and unstable trucking industry, and the need to upgrade the domestic logistics system.

Then the Committee outlines the required logistics infrastructure investment, the institutional changes and human resource requirements necessary to develop worldclass airports and seaports to increase competitiveness against rivals in Mainland China and Japan for transhipments from Northeast Asia where the international logistics system is still in its infancy. Seven key projects have been outlined: the rationalization of logistics infrastructure investment; the promotion of the logistics industry, including boosting the confidence of small-scale logistics companies; the enhancement of transparency in logistics transactions; the education of logistics professionals; the improvement of international logistics supporting schemes such as improving customs process procedures and establishing a Korean International Logistics Center; the integration of a logistics information system across all transportation networks; and the connection of Northeast Asian railroads, including standardization of the railroads of North and South Korea. This agenda is designed to develop Korea's 'inward globalization' by attracting the distribution centers and regional headquarters of multinational corporations and hi-tech industries so that the country becomes the Northeast Asian gateway for cargo, passengers and information. 
Inevitably, these developments in freight logistics policy in Australia and the Republic of Korea prompt the question: 'how relevant is Australia's experience in freight logistics to Korea?' In responding to this question the thrust of the Freight Logistics in Australia: An Agenda for Action, needs to be outlined and critically evaluated. Then its significance to the Korean situation can be assessed in a concluding comment. Before examining the Report, the Asia-Pacific region's freight transport logistics functions need to be located within the global hub-and-spoke system; the specific roles of Australia and Korea within this framework are identified and their implications noted.

\section{AUSTRALIA AND KOREA: SOME COMPARISONS}

There are marked economic and geographical differences between Australia and Korea, which are reflected in their respective freight logistics industries (Table 1). In 2002 Australia's land area was more than 72 times that of Korea. Yet Australia's population was only 40 per cent that of the Republic.

Although Korea had a slightly larger gross domestic product (GDP) Australia's GDP per capita was more than double that of Korea (Masamune, 2003). The per capita gap was beginning to narrow as Korea had a higher GDP growth rate than Australia. While inflation rates are more or less on a par, Australia's unemployment rate was more than double that of Korea. The value of both Korea's exports and imports were more than double those of Australia. Yet Australia's exports to Korea (A $\$ 9.2$ billion) were almost double its imports (A $\$ 4.7$ billion).

Table 1. Comparison between Australia and Korea, 2002

\begin{tabular}{l||r|r|c}
\hline & Australia & Korea & Ratio \\
\hline \hline Land area (sq. km.) & $7,137,000$ & 99,000 & 72.1 \\
\hline Population (million) & 19.7 & 48.1 & 0.4 \\
\hline GDP (US\$ billion) & 399.3 & 464 & 0.9 \\
\hline GDP per capita (US\$) & 20,262 & 9,654 & 2.1 \\
\hline Exports (US\$ billion) & 59.7 & 162.4 & 0.4 \\
\hline Imports (US\$ billion) & 63.5 & 152.1 & 0.4 \\
\hline
\end{tabular}

Source: Masamune (2003: 3.) 
These economic comparisons have to be augmented by a discussion of the relative positions of Australia and Korea in the global hub-and-spoke system, which underpins the worldwide movements of containers, air passenger and freight transport, and internet traffic (Fig. 2)

This hub-and-spoke system has emerged following the intensification of industrialisation in East Asia since the mid-1980s to provide global network corporations with a seamless, door-to-door logistics and supply chain management (SCM) system. Unlike Australia, Korea occupies a central location in this global system as an east-west aligned, world-spanning Main Street interconnects the continents in the northern hemisphere, Europe, Asia and North America. Conversely, Australia is at a disadvantage because, like Africa and Central and South America, it occupies a cul-de-sac position in the global hub-and-spoke system and, though airfreight is important in terms of value, its international freight task in tonnes and tonne-kilometres is dominated by the sea transport of primary commodity exports (Table 2). Within the global system, hubs at intersections on Main Street connect their respective terminals in north-south interactions with Africa, Australasia and South America. Thus Seoul-Incheon has a pivotal position in this global hub-andspoke arrangement whereas Sydney is essentially a terminal with its hub role being confined to interactions with the rest of Australasia, comprising New Zealand, Papua New Guinea and the Pacific Islands.

Figure 2. Australian transport: major seaports and national railways

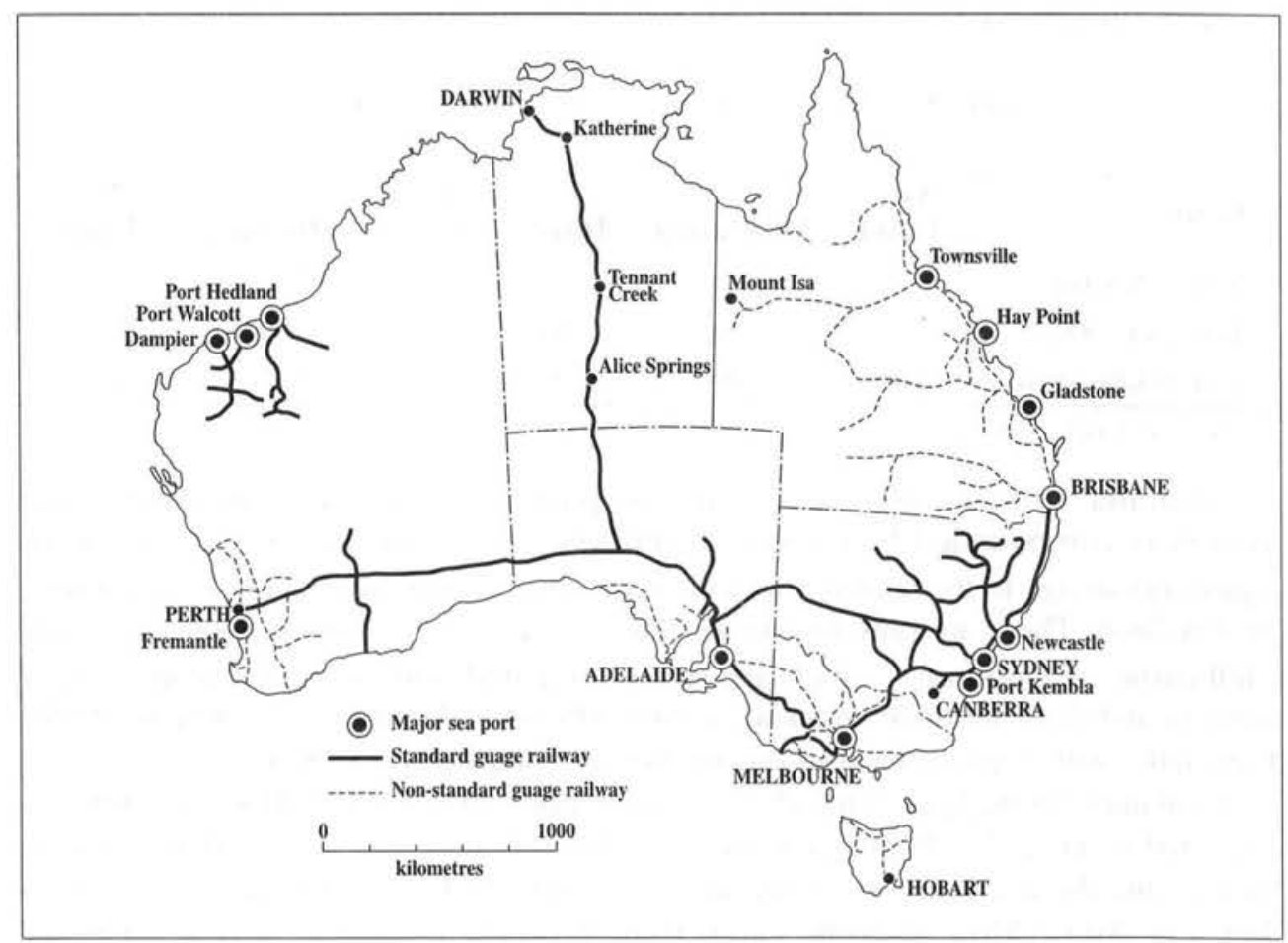

Source: based on BTRE (2003) 
Figure 3. Australian transport: international airports and national highways

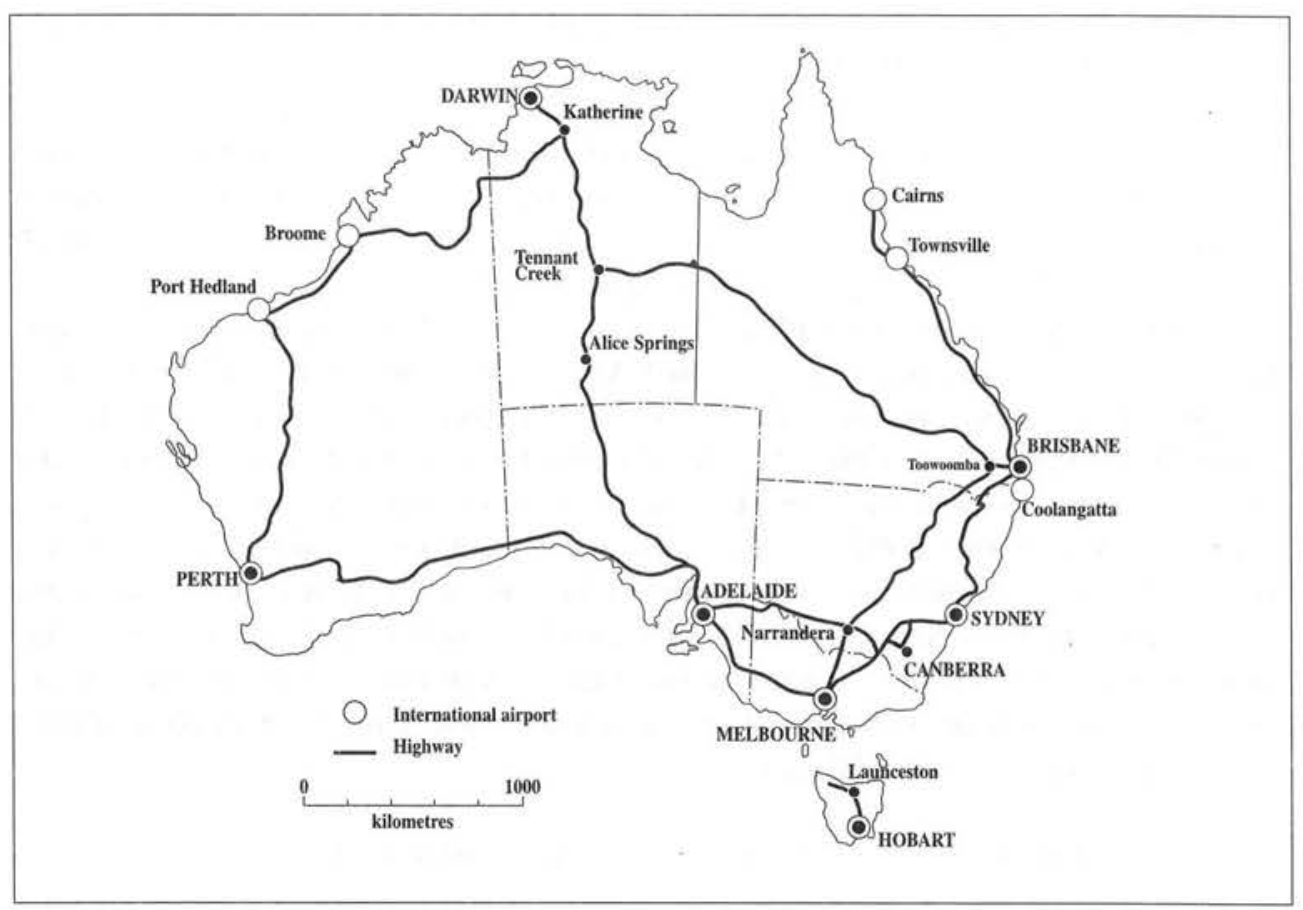

Source: based on BTRE (2003)

Table 2. Australia's International Freight Task, 2000-2001

\begin{tabular}{l||rcr|rrr}
\hline \multicolumn{1}{l||}{ Trade } & $\begin{array}{l}\text { Air } \\
\text { Load }\end{array}$ & Discharge & Total & $\begin{array}{l}\text { Sea } \\
\text { Load }\end{array}$ & Discharge & \multicolumn{1}{c}{ Total } \\
\hline \hline Value (\$A bn) & 24.8 & 40.9 & 65.7 & 99.4 & 83.0 & 181.3 \\
\hline Tonnes ('000s) & 350 & 294 & 644 & 495,714 & 54,408 & 550,122 \\
\hline Tonne-kms (mn) & 2,456 & 3,083 & 5,539 & $4,665,039$ & 522,711 & $5,186,750$ \\
\hline
\end{tabular}

Source: COA. (2002a: 19.)

Australia's disadvantageous $c u l$-de-sac position in the global hub-and-spoke system is compounded by having 20 million people spread across a continent equivalent in size to the United States in comparison with Korea' s closely distributed 48.7 million. There are only two large cities - Sydney (4.5 million population) and Melbourne (3.5 million)- which are small compared with Seoul-Incheon's (12.8 million) and there are three secondary centers (Brisbane-Gold Coast, Adelaide, PerthFremantle) with populations over one million in contrast to six in Korea.

Container throughput from all five major ports (3.3 million TEUs in 2000) is expected to grow by 45 per cent by 2010 but this will still be less than forecast movements through the port of Busan ( 7.5 million TEUs in 2000 and 11.6 million TEUs in 2011). Most seaborne cargo from Australia comprises bulk commodity exports such as coal and iron ore from the outports. 
The railways between capital cities are slow and under-resourced and, unlike the High Speed Railway between Seoul and Busan, the plans for an equivalent Australian version between Sydney and Melbourne have not materialized.

Despite the strong showing of rail and sea in tonne-kilometres there has been an overemphasis on road transport though there is still no undivided, inter-city expressway between Sydney and Melbourne to match the Kyongbu Expressway between Seoul and Busan (Table 3). Although airfreight is statistically insignificant it has a much greater role to play in Australian than Korea in moving time-sensitive commodities between non-adjacent states and in servicing remote locations.

Table 3. Australian Domestic Freight Task, 2000-2001

\begin{tabular}{l||rr|rr}
\hline \multirow{2}{*}{ Mode } & \multicolumn{2}{|c|}{ Tonnes (mill.) } & \multicolumn{2}{l}{ Tonne-kms (mill.) } \\
\hline \hline Road & 1,482 & 71.6 & 132,422 & 35.3 \\
\hline Rail & 535 & 25.9 & 137,700 & 36.7 \\
\hline Air & 0.15 & 0.0 & 248 & 0.1 \\
\hline Sea & 52 & 2.5 & 104,501 & 27.9 \\
\hline Total & 2,069 & 100.0 & 374,781 & 100.0 \\
\hline
\end{tabular}

Note: rounding errors.

Source: DOTARS (2003.)

These drawbacks in Australia's freight transport logistics in comparison with Korea have been aggravated by the division of responsibilities in a federal system of government between the Australian (Commonwealth) Government and the state governments, low levels of inter-modal cooperation and the lack of an integrated national transportation plan. Under these circumstances there has been a call from major transport modes and users for government to address these freight logistics issues. Over the past decade the Australian Government has commissioned a number of reports and task forces but they have not led to concerted action. Not surprisingly, the Australian Government's renewed interest in transportation issues at the beginning of the new millennium was met with widespread cynicism. The success of the 'Supermarket to Asia' Action Agenda, with a mission to grow Australian food sales to Asia and increase the number of exports by improving quality standards in cold chain management of perishable goods, however, suggests that the government, whatever its underlying rationale, and the freight logistics industry could work together to achieve common goals.

\section{AUSTRALIAN FREIGHT LOGISTICS ACTION AGENDA}

As noted, in May 2000 the Australian Government supported the development of a new Action Agenda for the Australian freight logistics industry, which, according to the Department of Transport and Regional Services (DOTARS (2001: 1), 'aims to identify and address impediments to growth and offer the opportunity to create a sustainable, internationally competitive freight transport logistics industry'. 
By January 2001 the Government had established a twenty-member Industry Steering Committee to support the development of the Action Agenda with members drawn from major transport companies, peak industry bodies, federal and state government departments, ports, shippers, transport consultants and universities. As this Committee was responsible for developing the Action Agenda, the process, according to its Chairman, John Bowdler, 'provided the freight logistics industry and the users of its services with an invaluable opportunity to examine the factors most critical to the industry' s future' (COA, 2002a: iii). Further, the process 'enabled the industry to be pro-active in proposing a comprehensive suite of actions to improve the competitiveness of one of the most influential parts of the economy and establish a new basis for effective relationships across the industry and with governments'

Initially, the Committee held consultations with large, medium and small enterprises, government and academic stakeholders. By March 2001 three working groups were established to discuss industry directions, information and communications technology and business process engineering, and education and training. In April 2001 a Discussion Paper entitled Linking Ahead was released by the Committee, which summarized the findings of past reports to assess issues, identify opportunities and raise questions (DOTARS, 2001). Then in October 2001 the Committee's Consultation Draft was circulated for comment by the end of the year. By March 2002 an amended draft was sent to the Industry Leaders Roundtable. After further amendment the Final Report appeared in May 2002 (COA, 2002a).

The Final Report describes the industry's significance to the economy and its structure using work by the Bureau of Transport and Regional Economics (BTRE, 2001) and a study commissioned from the Allen Consulting Group (2001) of comparative public policies across a range of countries, including Japan but not Korea. Then the Report identifies the challenges for freight logistics in Australia, the key issues that have to be addressed by the Action framework, the need for a fresh approach to relations between industry and government through the establishment of joint-body, the Australian Logistics Council, and recognition that the time was ripe for a partnership between industry and government. Going beyond the Report, the establishment of the Australian Logistics Council and the implications of its initial meetings are discussed.

\section{Industry Structure and Significance to the Economy}

In 1999-2000 the Bureau of Transport and Regional Economics (BTRE, 2001) estimated from past research that the freight logistics sector cost 9 per cent of Australia' $\mathrm{s}$ gross domestic product (GDP) or US $\$ 33.6$ billion. Although freight logistics is one of the biggest sectors of the Australian economy it is at the lower end of the spectrum in overseas studies as Korea recorded 12.4 per cent in 2002 (PCNABH, 2003). In-house logistics activities accounted for 54 per cent of the value of logistics activities in Australia. The remaining private and government shippers outsource to the growing freight logistics industry that includes the larger firms of Toll Holdings, Mayne Logistics TNT Australia, BHP Transport and Logistics Group, Linfox Transport and $\mathrm{K} \& S / S c o t t$ Group, accounting for one-third of all revenue, and prominent overseas operators, notably Danzas AEI, Excel and EGL Eagle Global Logistics (BTRE, 2001). 
Their number includes contractors/specialists, brokers/agents, multi-service logistics operators engaged in transport and warehousing (e.g. Lang Corporation) and integrated service integrators offering users complete logistics solutions, typified by Danzas AEI (computers) and Excel (health care and pharmaceutical products). Reforms in both rail and road have facilitated the emergence of Australian integrated logistics providers. However, after the takeover of TNT by the Dutch post office, no Australian providers are comparable in size to Korea's Hyundai Merchant Marine or Hanjin Shipping, which are ranked in the world's top logistics and freight transport group (Damas, 2003).

Lack of data precluded assessments of the freight logistics industry' s performance but several case studies were cited to highlight the savings to be derived from improved logistics (COA, 2002a: 26). Compass Logistics introduced co-delivery for three clients and reduced costs by 30 per cent; Smorgon Steel had a once-off saving of $\$ \mathrm{~A} 3$ million by reducing its inventory and an annual saving of $\mathrm{A} \$ 3$ million by cutting transport costs; and BHP Transport and Logistics saved 10-30 per cent in logistics chain costs (COA, 2002a: 26). These results replicated those of overseas firms. For example, Sainsburys in the United Kingdom received a 500 per cent return within two years from adopting a logistics planning system; Maersk Logistics halved an American client's US\$10.8 million inventory; and Harley Davidson overhauled its logistics chain and not only reduced material costs by US\$40 million but also used these savings in development costs to boost responsiveness to customer demands.

\section{Challenges for Freight Logistics in Australia}

Australia has to develop 'a dynamic and sustainable freight logistics industry if it is to remain a globally competitive economy'. Before Australia can achieve this overriding goal the 'industry must work smarter - not just in terms of the equipment and the technology it uses - but in the knowledge and relationships it develops among individual components of logistics chains. Consequently, 'if Australia applies its skills and experience it will become a valuable, sought-after participant in global logistics chains while still delivering local solutions for local needs' (COA, 2002a:xii). Before Australia can become a valuable sought-after participant the freight industry and governments have to address five challenges.

Traditional modal interests must subsume their interests in a multimodal perspective so that freight logistics can be considered at a higher level. Strong leadership is required to produce a unified industry perspective and to introduce knowledge and relationships -the twin drivers of economic success - to transform the industry' s culture.

Inadequate freight logistics infrastructure, reflected in road congestion, impediments to rail competition and restrictions on port operations, needs to be upgraded to lessen transport costs and enable the full range of services being supplied to businesses located in rural and regional Australia. The career profile of the industry is tarnished by its 'old economy' image of being 'dirty, difficult and dangerous', which makes it problematic for logistics firms to transform their ageing, maledominated, workforce by introducing younger people and attracting logistics professionals with suitable qualifications into what is increasingly becoming a knowledge-based industry. 
Community attitudes troubled by adverse environmental outcomes (e.g. accidents and pollution) need to appreciate the importance of freight logistics in their everyday lives because public pressure is impeding the development and maintenance of urban infrastructure, which is leaving the industry vulnerable to inappropriate environmental policies.

Australian, state and local governments need to recognize the significance of the freight logistics industry and its contribution to the economy by coordinating policies that address the hard issues - leadership, infrastructure and people - and supplying programs that facilitate the development of world competitive logistics chains.

Recently, these challenges have been intensified by government and consumer reactions to terrorism, which are demanding higher levels of freight security and integrity from the freight logistics industry.

\section{Key Issues for the Action Framework}

In addressing these challenges the Action Agenda had to recognize the need to overcome the lack of suitable data for assessing the performance of the freight logistics industry; educate the business community about the benefits of adopting best practice appropriate for Australian firms, particularly small and medium enterprises; and combine best practice, performance monitoring and benchmarking with best practice e-Business technologies and intelligent transport systems to provide customers with the best possible logistics services including track and trace systems and freight matching services (COA, 2000a: 31-47). Also improvement in occupational health and safety and investment in training people within the industry is required, together with flexible operating arrangements to meet changing customer demands while addressing social amenity, environmental outcomes and the costs of urban congestion, which will increase from $\mathrm{A} \$ 13$ billion to $\mathrm{A} \$ 30$ billion annually by 2015 (COA, 2000a: 47-74). In addition, the industry had to work with all levels of government in Australia - federal, state and local- to inject a broader freight logistics approach to government regulation and industry accreditation, and to guide government decision-making.

\section{The Need for a Fresh Approach}

Before a competitive, sustainable and dynamic freight logistics industry can be realized the top echelon of both industry and governments have to change their past approaches and adopt a three-year plan for addressing five key priorities:

leadership

infrastructure

people

innovation through technology and knowledge

sustainability.

As summarized in Table 4, these priorities were supported by key priority actions: the need to establish the Australian Freight Logistics Council; to develop a strategic 
infrastructure framework for transport, storage and warehousing and communications; to develop a national training education and training framework; to address inter-connectivity of systems in e-Logistics; to enhance data and analysis; and to promote environmental accreditation. In turn, there were 30 recommended supporting actions.

Table 4. Freight Logistics Priorities and Actions

\begin{tabular}{|c|c|c|}
\hline PRIORITY & Priority Action & Supporting Action \\
\hline $\begin{array}{l}\text { LEADERSHIP } \\
\text { Implementation \& } \\
\text { development }\end{array}$ & $\begin{array}{l}\text { Establish the Australian } \\
\text { Logistics Council }\end{array}$ & $\begin{array}{l}\text { Establish national industry } \\
\text { consultative framework; Australian } \\
\text { Transport Council support; \& } \\
\text { Coordinate government activities. }\end{array}$ \\
\hline Regulation & & $\begin{array}{l}\text { Review progress in regulatory } \\
\text { reform; Broaden approach to } \\
\text { regulatory reform; \& Insurance \& } \\
\text { liability review. }\end{array}$ \\
\hline Exporting services & & $\begin{array}{l}\text { Review export performance; \& } \\
\text { Promote global logistics chain } \\
\text { capabilities. }\end{array}$ \\
\hline INFRASTRUCTURE & $\begin{array}{l}\text { Develop strategic } \\
\text { framework }\end{array}$ & $\begin{array}{l}\text { Secure transport corridors; Assist } \\
\text { freight center planning; Review } \\
\text { Federal infrastructure funding; Audit } \\
\text { logistics facilities; Audit access } \\
\text { regimes; \& Audit rail reform. }\end{array}$ \\
\hline $\begin{array}{l}\text { PEOPLE } \\
\text { Education \& training }\end{array}$ & $\begin{array}{l}\text { Develop national } \\
\text { training education \& } \\
\text { training framework }\end{array}$ & $\begin{array}{l}\text { Promote career training \& training } \\
\text { opportunities; Develop learning } \\
\text { networks; Create education \& training } \\
\text { web portal; \& Review education \& } \\
\text { training funding. }\end{array}$ \\
\hline Workplace relations & & $\begin{array}{l}\text { Promote more flexible work } \\
\text { arrangement; \& Improve } \\
\text { occupational health \& safety. }\end{array}$ \\
\hline \multicolumn{3}{|l|}{$\begin{array}{l}\text { INNOVATION } \\
\text { THROUGH } \\
\text { TECHNOLOGY \& } \\
\text { KNOWLEDGE }\end{array}$} \\
\hline \multirow[t]{2}{*}{ Strategic knowledge } & $\begin{array}{l}\text { Address inter- } \\
\text { connectivity of systems } \\
\text { Enhance data \& } \\
\text { analysis }\end{array}$ & $\begin{array}{l}\text { Demonstrate benefits of e-logistics; \& Improve } \\
\text { freight distribution throughe-Logistics. } \\
\text { Provide best practice information } \\
\text { packages; Produce template service }\end{array}$ \\
\hline & & $\begin{array}{l}\text { level agreements; \& Review } \\
\text { accreditation arrangements. }\end{array}$ \\
\hline $\begin{array}{l}\text { Innovation, research } \\
\& \text { development }\end{array}$ & & $\begin{array}{l}\text { Analyse innovation processes; \& Improve } \\
\text { research \& development capabilities. }\end{array}$ \\
\hline SUSTAINABILITY & $\begin{array}{l}\text { Promote environmental } \\
\text { accreditation }\end{array}$ & $\begin{array}{l}\text { Reduce congestion \& emissions; } \\
\text { Life cycle assessments to reduce } \\
\text { environmental impacts; \& Eliminate } \\
\text { packaging waste. }\end{array}$ \\
\hline
\end{tabular}

Source: Distilled from COA (2002a: xiv-xv.) 
The key recommendation was that the Australian Logistics Council be established, comprising twenty-five members drawn from the providers and users of freight logistics, the Australian and state governments, and education and training providers. The Council's tasks are to: drive the implementation of the Action Agenda; set implementation priorities and milestones; develop links with initiatives at State, Territory, regional and local levels; hold an annual stakeholders' forum to evaluate progress; and facilitate the evaluation of the Action Agenda's impact after three years, and again after five years.

\section{Ripe for Change}

The time is seen as being apposite for a new partnership between a pro-active freight logistics industry and all levels of government (COA, 2000a: 93-102). This prospect has been facilitated by a series of recent changes - including two decades of micro-economic reform involving deregulation and privatization - that have enabled the industry to provide multi-modal transport and a full range of logistics activities, particularly with the growth of specialist services and systems, and information and communications technology. Providing the proposed education and training program can produce a desirable employment structure within the industry, there is scope for exporting the intellectual property associated with freight logistics and related services to other countries, such as Korea, and entering into collaborative arrangements with Korean companies to export services to a third country. If these opportunities are not realized it is likely that the industry will fail to attract younger employees and logistics professionals; other countries, like Korea, will proceed to develop their own world-class freight logistics industries; and Australian firms would not be ready to join global logistic chain leaders. Given this scenario it is not surprising that Australian Government endorsed the freight logistics industry's final recommendations and the

Australian Logistics Council, modelled on the private, non-profit Holland Distribution Industry Council, was established to provide on-going high-level industry-government consultative arrangements (COA, 2002b; HIDC, 2003).

\section{The Australian Logistics Council}

In September 2002 the Australian Logistics Council met for the first time. The Council was chaired by the Minister for Transport and Regional Services and Deputy Prime Minister (John Anderson) and comprised twenty-five high profile members (DOTARS, 2002a). The Council was split into four Steering Groups on infrastructure, people, regulation and leadership. By November 2002 these Groups reported back to Council's second meeting (DOTARS, 2002b). An Annual Report on the implementation of the Action Agenda has to be delivered to the Minister of Transport and Regional Development and forwarded to the Australian Transport Council.

There is some ambivalence about the involvement of the Minister of Transport and Regional Services, who is also Deputy Prime Minister, as Chair of the Australian Logistics Council (Crisp, 2003). 
Some see his appointment as evidence that the Australian Government is taking freight logistics seriously. Others claim that the Deputy Prime Minister will be too involved with other matters to drive the Council's agenda. Should the latter scenario prevail, high profile members may quickly lose interest in the Council. Alternatively, some argue that if a well-resourced Council were driven by the freight logistics industry it would make faster progress in working through the Action Agenda. Whichever thrust prevails the Council has to produce tangible results before attracting continuing involvement from the industry's top echelon of decision makers.

\section{CONCLUSIONS: RELEVANCE TO KOREA?}

Both the Australian Government and the Korean Government have now realized if belatedly - that it is not sufficient to concentrate on the traditional freight transportation view. Attention must be shifted to a freight logistics perspective. The Australian Government's pioneering Action Agenda on Freight Logistics that provides 'the will and means' for Australian industry 'to trade anywhere, anytime' may have some relevance to the Korean Government's vision of becoming the logistics hub of Northeast Asia (COA, 2002a: xv; PCNABH, 2003). Getting the freight transport logistics industry in Korea to provide a similar comprehensive overview to that supplied in Australia would deepen an appreciation of existing issues and future directions. As in Australia, the resultant blueprint could lead to a fruitful dialogue between the Korean Government and the freight logistics industry in Korea. Of course, perspectives on particular issues may differ between Australia and Korea but that is surely the intrinsic value of educational and training institutions undertaking comparative public policy studies on freight logistics in different countries. Surely the marked differences between the logistics situations in Australia and Korea offer a fruitful ground for mutual cooperation in educating logistics professionals and scope for developing a joint program between a Korean Logistics Graduate School and Logistics Institutes in Australia (see LAA, 2003 for Logistics Association of Australia: Education Directory).

One possible shortcoming of the Australian Freight Logistics Action Agenda has been its failure to focus more fully on external relations, particularly with the AsiaPacific region. This lack of an Asia-Pacific regional context is being compounded in the Australian Government's Green Paper entitled AusLink: Towards the National Land Transport Plan, which is designed 'to transform separate road, rail and intermodal links into an integrated, high performing land transport network' (DOTARS, 2003: 1). While AusLink identifies key corridors for meeting the anticipated doubling of the freight transport task by 2020 and an accompanying 50 per cent increase in urban freight and passenger movements, the Green Paper is preoccupied with national planning. Unlike The Republic of Korea's (ROK, 2000) Fourth Comprehensive National Territorial Plan, 2000-2020, which highlights the country's external connections, there is little reference to Australia's position within Asia-Pacific region. 
Greater consideration needs to given in Australia's proposed rolling five-year National Land Transport Plan as to how the country could be more closely integrated into the Asia-Pacific region by adopting a spatial strategy that would better distribute economic activity by working with, rather than against, international pressures. While Sydney will undoubtedly maintain its dominant status as Australia's main international gateway, greater impetus could be given to developing Brisbane and Fremantle as major gateways. By using improved transport corridors to link Melbourne and Adelaide through these gateways there would be an opportunity to regenerate their manufacturing bases with hi-tech activities. In these ways the freight logistics strategy would not only consolidate a national market but also provide a mechanism for closer integration with international markets, particularly those in the Asia-Pacific region. There is an urgent need to address this issue in the Australian Government's forthcoming White Paper AusLink - Australia's first National Land Transport Plan, which will guide investment from June 2004

\section{REFERENCES}

Allen Consulting Group (2001) Comparative Public Policy on Freight Logistics: Report to the Department of Transport and Regional Services - June 2001, Canberra, Department of Transport and Regional Services.

http://www.dotars.gov.au/transinfra/freight logistics.htm

BTRE (2001) Logistics in Australia: A Preliminary Analysis, Working Paper 49, Canberra, Bureau of Transport and Regional Economics. http://www.btre.gov.au/docs/wp49 contents.htm

BTRE (2003) Australian Transport Statistics 2003, Canberra, Bureau of Transport and Regional Economics.

http://www.btre.gov.au/docs/trnstates03/trnstats.htm

COA (2002a) Freight Logistics in Australia: An Agenda for Action, Canberra, Commonwealth of Australia. http://www.dotars.gov.au/logistics

COA (2002b) Freight Logistics in Australia: Commonwealth Government's Response, Canberra, Commonwealth of Australia.

Crisp, D. (2003) 'The grand plan', Containerisation International, March: 75-77.

DIST, n.d. Action Agendas, Canberra, Department of Science Industry and Technology. http://www1.industry.gov.au/archive/growth/html/actions,html

DOTARS (2001) Australian Freight Transport Logistics Industry Action Agenda:

Industry Steering Committee Discussion Paper: Linking Ahead, Canberra, Department of Transport and Regional Services.

http://www.dotars.gov.au/transinfras/aftliaa/linking ahead.htm

DOTARS (2002a) Australian Logistics Council Inaugural Meeting 5 September 2002 Parliament House, Canberra, Department of Transport and Regional Services. http://www.dotars.gov.au/transinfras/alcminsept.him

DOTARS (2002b) Australian Logistics Council $2^{\text {nd }}$ Meeting 7 November 2002 Radisson Plaza, Sydney, Canberra, Department of Transport and Regional Services. http://www.dotars.gov.au/transinfra/alcminnov.htm 
DOTARS (2003) Transport and Infrastructure Policy: AUSLINK - Green Paper,

Foreword by John Anderson, Canberra, Department of Transport and Regional Services. http://www.dotars.gov.au/transinfra/auslink/greenpaper.htm

Damas, P. (2003) 'Logistics, transport groups pause for thought', American Shipper, October: 24-28.

HIDC (2003) Holland International Distribution Council, The Hague. http://www.hidc.nl

LAA (2003) Logistics Association of Australia; Education Directory, Canberra, Logistics Association of Australia. http://www.laa.asn.au/educaton.htm

Masamune, E. (2003) Korea: Opportunities for Australia, August 2003, Seoul, Australian Embassy. http://www.austrade.or.kr/upload/General\%20message.pdf

PCNABH (2003) Road Map for Promoting Northeast Asian Logistics Hub, October 2003, Seoul, Presidential Committee on Northeast Asian Business Hub.

ROK (2002) Jae-4-cha Kuk to Jong-hab Gae-wheok, 2000-2020 [The Fourth Comprehensive National Territorial Plan, 2000-2020], Seoul, Dae Han Min Kuk Jung Pan [Republic of Korea].

Rimmer, P.J. (2001) 'A cul-de-sac off Main Street: transport', in C. Sheil (ed.), Globalisation: Australian Impacts, Sydney, University of New South Wales Press Ltd: 35-57. 